\title{
Relationship of the aberrant DNA hypermethylation of cancer-related genes with carcinogenesis of endometrial cancer
}

\author{
KOUJI BANNO*, MEGUMI YANOKURA*, NOBUYUKI SUSUMU, MAKIKO KAWAGUCHI, \\ NOBUMARU HIRAO, AKIRA HIRASAWA, KATSUMI TSUKAZAKI and DAISUKE AOKI \\ Department of Obstetrics and Gynecology, Keio University School of Medicine, Tokyo, Japan
}

Received July 5, 2006; Accepted August 28, 2006

\begin{abstract}
Epigenetic abnormalities including the aberrant DNA hypermethylation of the promoter $\mathrm{CpG}$ islands play a key role in the mechanism of gene inactivation in cell carcinogenesis. To identify the genes associated with aberrant DNA hypermethylation in endometrial carcinogenesis, we studied the hypermethylation of the promoter regions of five genes: $h M L H 1, A P C, E$-cadherin, $R A R-\beta$ and $p 16$. The frequencies of aberrant hypermethylation were $40.4 \%$ (21/52) in $h M L H 1$, $22 \%(11 / 50)$ in $A P C, 14 \%(7 / 50)$ in E-cadherin, and $2.3 \%$ $(1 / 44)$ in $R A R-\beta$ in endometrial cancer specimens. No aberrant DNA methylation was found in p16. In atypical endometrial hyperplasia, the frequencies of aberrant methylation were $14.3 \%(2 / 14)$ in $h M L H 1$ and $7.3 \%(1 / 14)$ in $A P C$, whereas normal endometrial cells showed no aberrant hypermethylation of any of the five genes. The high frequencies of the aberrant DNA hypermethylation of $h M L H 1, A P C$ and E-cadherin suggest that the methylation of the DNA mismatch repair and Wnt signal-related genes may be associated with endometrial carcinogenesis.
\end{abstract}

\section{Introduction}

The relationship of cellular oncogenic transformation with aberrant DNA hypermethylation in promoter regions (i.e., epigenetic changes) is an area of growing interest. Genes ranging from tumor suppressors to DNA mismatch repair and cell cycle-related genes are known to be inactivated by aberrant DNA methylation in cancer. The DNA mismatch repair genes human MutL homolog-1 (hMLHl) and human MutS homolog (hMSH2) function in the repair of base-pair

Correspondence to: Dr Kouji Banno, Department of Obstetrics and Gynecology, Keio University School of Medicine, Shinanomachi 35, Shinjuku-ku, Tokyo 160-8582, Japan

E-mail: kbanno@sc.itc.keio.ac.jp

${ }^{*}$ Contributed equally

Key words: endometrial cancer, DNA hypermethylation, human MutL homolog-1, E-cadherin, adenomatous polyposis coli, retinoic acid receptor- $\beta$ mismatches that occur in gene amplification during cell division. The characteristic seen in cancer cells when the DNA mismatch repair system breaks down is referred to as microsatellite instability (MSI). Microsatellites are repeated DNA sequences of $\sim 1$ to 5 bases, and DNA replication errors occur frequently at these sites upon the inactivation of the DNA mismatch repair genes. MSI is detected in $\sim 40 \%$ of patients with endometrial cancer $(1,2)$, suggesting that mutations of the DNA mismatch repair genes are associated with endometrial carcinogenesis. Therefore, in this study we examined the aberrant DNA methylation of $h M L H 1$, a leading candidate in the DNA mismatch repair gene group regarding the production of MSI.

The $\beta$-catenin gene codes for a cell adhesion molecule that plays a key role in the Wnt signaling pathway and is generally localized in the cell membrane, where it binds to $E$-cadherin, an adhesion molecule. Free $\beta$-catenin forms a complex with adenomatous polyposis coli $(A P C)$ and axin is phosphorylated by GSK-3ß and degraded via the proteosome pathway. The mutation of the $\beta$-catenin gene increases the level of undegraded $\beta$-catenin in the cells and causes the transition of $\beta$-catenin into the nucleus, which induces the activation of the Wnt signaling pathway and enhances the transcriptional activity of target genes including cyclin $D$, leading to cell cycle aberrations. The activation of the Wnt signaling pathway is also thought to be important in endometrial carcinogenesis (3), and therefore $E$-cadherin and $A P C$, which are components of the Wnt signaling pathway, are also candidate genes for aberrant DNA methylation in endometrial cancer.

p16 is a tumor suppressor gene that codes for a protein that binds to CDK4 and CDK6 and inhibits the phosphorylation of the RB/E2F complex by the CDK-Cyclin D. p16knockout mice develop multiple cancers in different organs, and therefore $p 16$ inactivation is thought to play an important role in cell carcinogenesis. The frequencies of p16 mutation and deletion in endometrial cancer are only 5-6\% and 3\%, respectively $(4,5)$, but reduced protein levels have been found in $19 \%$ of cases (5), and this may be associated with aberrant DNA methylation.

Type I endometrial cancer is also estrogen-dependent; estrogen increases the risk of endometrial cancer through a mechanism that has yet to be fully explained. Estrogen acts in a receptor-specific manner as a molecular switch to regulate transcription factor function. Estrogen receptors have highly differentiated structures, and aberrant methylation of the estrogen receptor (ER) gene in endometrial cancer has 
Table I. Primer sequences used in MSP analysis and RT-PCR.

\begin{tabular}{|c|c|c|c|c|}
\hline $\begin{array}{l}\text { Gene } \\
\text { name }\end{array}$ & PCR analysis & Sense & Antisense & $\begin{array}{l}\text { Size Ann }{ }^{\mathrm{a}} \\
\text { (bp) temp } \\
\left({ }^{\circ} \mathrm{C}\right)\end{array}$ \\
\hline \multirow[t]{2}{*}{$h M L H 1$} & Methylated & ACGTAGACGTTTTATTAGGGTCGC & CCTCATCGTAACTACCCGCG & 11260 \\
\hline & Unmethylated & TTTTGATGTAGATGTTTTATTAGGGTTGT & ACCACCTCATCATAACTACCCACA & 12460 \\
\hline \multirow[t]{2}{*}{$A P C$} & Methylated & TATTGCGGAGTGCGGGTC & TCGACGAACTCCCGACGA & 10068 \\
\hline & Unmethylated & GTGTTTTATTGTGGAGTGTGGGTT & CCAATCAACAAACTCCCAACAA & 11067 \\
\hline \multirow[t]{2}{*}{$R A R-\beta$} & Methylated & GGTTAGTAGTTCGGGTAGGGTTTATC & CCGAATCCTACCCCGACG & $235 \quad 59$ \\
\hline & Unmethylated & TTAGTAGTTTGGGTAGGGTTTATT & ССАААТССТАССССААСА & 23359 \\
\hline \multirow[t]{2}{*}{ pl6 } & Methylated & TTATTAGAGGGTGGGGCGGATCGC & GACCCCGAACCGCGACCGTAA & 15067 \\
\hline & Unmethylated & TTATTAGAGGGTGGGGTGGATTGT & CAACCCCAAACCACAACCATAA & 15166 \\
\hline
\end{tabular}

${ }^{\mathrm{a} A n n e a l i n g ~ t e m p e r a t u r e . ~}$

been reported (6). The $E R$ protein shares a common fold with glucocorticoid and retinoic acid receptors (these receptors all belong to the nuclear receptor superfamily), but the frequency of the aberrant methylation of the retinoic acid receptor- $\beta$ $(R A R-\beta)$ gene in endometrial cancer has not been determined. However, studies of cancers in other organs $(7,8)$ suggest a relationship between those cancers and the aberrant DNA methylation of $R A R-\beta$.

To identify genes associated with aberrant DNA methylation in endometrial carcinogenesis, we studied the aberrant DNA methylation of the promoter regions of five genes (hMLH1, APC, E-cadherin, RAR- $\beta$ and p16) that show high frequencies of aberrant DNA methylation in different cancers and may be important in endometrial carcinogenesis.

\section{Materials and methods}

Clinical specimens. The subjects were 93 patients who gave informed consent to the collection of endometrial specimens (27 normal endometria, 14 atypical endometrial hyperplasia, and 52 endometrial cancers). The cells obtained from the tissue specimens were examined by liquid-based cytology using the ThinPrep system (Cytyc Corporation, Boxborough, MA, USA) with preservation fluid (PreservCyt Solution, Cytyc Corporation) (9). A pathological diagnosis of the endometrial tissue was consistent with the cytology results for all the 93 subjects. Of the 27 patients with a normal endometrium, 16 were in the secretory phase and 11 were in the proliferative phase. Of the 52 patients with endometrial cancer, 44 had ovarian endometrioid adenocarcinoma $(\mathrm{G} 1,24 ; \mathrm{G} 2,10 ; \mathrm{G} 3,10)$ and 8 had adenosquamous carcinoma. The grade of histological differentiation (G1 to G3) and the cancer stage at surgery were determined based on the Guidelines for Endometrial Cancer published by the Japan Society of Obstetrics and Gynecology.

DNA extraction and methylation-specific PCR (MSP) analysis. DNA was extracted from 93 endometrial specimens using liquid-based cytology with a Get Pure DNA kit (Dojindo Molecular Technologies Inc., Kumamoto, Japan). Distilled water was added to $1 \mu \mathrm{g}$ of the extracted DNA up to a volume of $50 \mu 1,5.5 \mu 13 \mathrm{~N} \mathrm{NaOH}$ solution was added, and, after mixing, the solution was incubated at $37^{\circ} \mathrm{C}$ for $15 \mathrm{~min}$. Following this, $520 \mu 13 \mathrm{M}$ sodium bisulfite (Sigma, St. Louis, MO, USA), which was prepared at pH 5.5 with $30 \mu 1$ $10 \mathrm{mM}$ hydroquinone (Sigma) and $10 \mathrm{~N} \mathrm{NaOH}$, was added to the solution. After mixing in an upturned position to prevent vaporization, the solution was overlaid with mineral oil and incubated at $50^{\circ} \mathrm{C}$ overnight. Next, $1 \mathrm{ml}$ clean-up resin (Promega Corporation, Madison, WI, USA) was added to the lower layer, and the resulting solution was mixed in an upturned position and then injected into a column. After rinsing with $2 \mathrm{ml} 80 \%$ isopropanol, the column was centrifuged at $15,000 \mathrm{rpm}$ for $3 \mathrm{~min}$ to remove the isopropanol completely, after which $50 \mu \mathrm{l}$ distilled water $\left(70^{\circ} \mathrm{C}\right)$ was added directly to the column, and the column was centrifuged at 15,000 rpm for 2 min to extract the DNA adsorbed in the column. Then, 5.5 $\mu 1$ $2 \mathrm{~N} \mathrm{NaOH}$ was added to the resulting DNA solution, and, after mixing, the solution was incubated at $37^{\circ} \mathrm{C}$ for $20 \mathrm{~min}$, after which $66 \mu 15 \mathrm{~N}$ ammonium acetate solution and $243 \mu 1$ $95 \%$ ethanol were added, and the solution was incubated at $80^{\circ} \mathrm{C}$ for $1 \mathrm{~h}$ and centrifuged at $15,000 \mathrm{rpm}$ for $30 \mathrm{~min}$ to precipitate the DNA. Approximately $50 \mu 1$ of the supernatant was left in the tube, and the rest of the supernatant was collected, mixed with $1 \mathrm{ml} 70 \%$ ethanol, and then centrifuged at 15,000 rpm for $30 \mathrm{~min}$ to rinse the DNA. The precipitated DNA was air-dried and dissolved in $20 \mu 1$ distilled water; $2 \mu 1$ of this solution was used as the MSP template solution. AmpliTaq Gold \& $10 X$ PCR buffer $/ \mathrm{MgCl}_{2}$ with dNTP (Applied Biosystems, Foster City, CA, USA) was used in the PCR analysis, and the DNA was analyzed using a GeneAmp PCR 9700 system (Applied Biosystems). A CpG WIZ E-cadherin amplification kit (Chemicon, Temecula, CA, USA) was used as the MSP for the E-cadherin gene. The PCR conditions and primer sequences for the other genes are shown in Table I.

Immunohistochemical analysis of endometrial cancer tissues. Twenty surgical endometrial specimens from 52 patients were examined using liquid-based cytology. Formalin-fixed, 

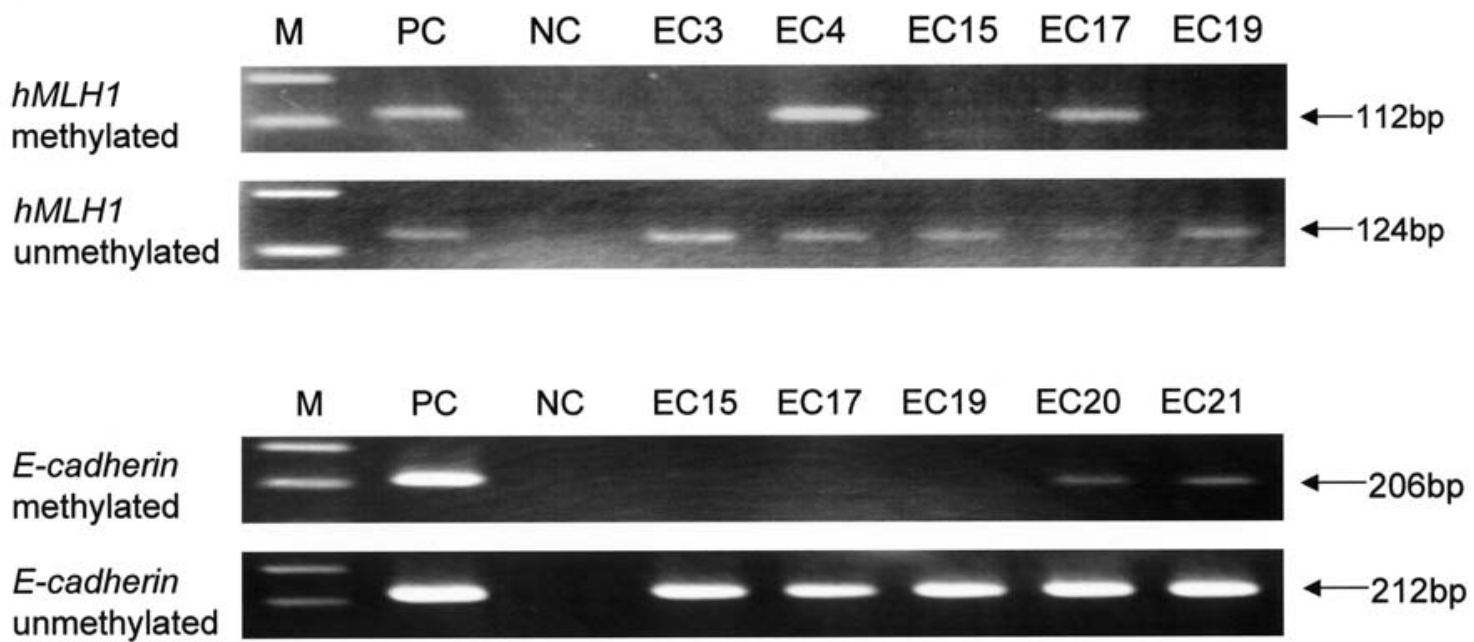

Figure 1. MSP analysis of the $h M L H 1$ and E-cadherin genes in endometrial cancer specimens. MSP analysis was conducted using DNA extracted from endometrial cancer specimens. The results for $h M L H 1$ and E-cadherin are shown in the upper and lower panels, respectively. For $h M L H 1$ the aberrant methylation band is shown in lanes EC4 and EC17, and for E-cadherin this band is shown in lanes EC20 and EC21. M, marker; PC, positive control; NC, negative control; EC, endometrial cancer.

paraffin-embedded specimens were prepared and the slices were stained in a silane-coated slide using a Vectastain ABC kit (Vector Laboratories, Burlingame, CA, USA). After deparaffinizing, the slides were heated in $10 \mathrm{mM}$ citric acid buffer solution $\left(\mathrm{pH} \mathrm{7.0)}\right.$ ) at $120^{\circ} \mathrm{C}$ for $10 \mathrm{~min}$ in an autoclave for antigen retrieval. After allowing the slides to cool to room temperature, intrinsic peroxidase activity was eliminated by treating the slides with $3 \% \mathrm{H}_{2} \mathrm{O}_{2}$ in phosphate-buffered saline (PBS) for $5 \mathrm{~min}$. The slides were rinsed twice with PBS and blocked with normal goat serum, and then rinsed twice again with PBS and diluted with $1 \%$ bovine serum albumin (BSA) in PBS and incubated with the primary antibody at $4^{\circ} \mathrm{C}$ overnight. The primary antibodies were the 50 -fold diluted anti- $h M L H 1$ antibody (BD Bioscience Pharmingen, San Diego, CA, USA) and the 500-fold diluted anti-E-cadherin antibody (Takara, Tokyo, Japan). After rinsing three times with PBS, the slides were incubated with the secondary antibody (biotin-labeled anti-mouse $\mathrm{IgG}$ ) at room temperature for $30 \mathrm{~min}$. After rinsing three more times with PBS, the slides were incubated with $\mathrm{ABC}$ (avidin-biotin peroxidase) complex at room temperature for $30 \mathrm{~min}$. After further rinsing three times with PBS, the slides were treated with $0.2 \mathrm{mg} / \mathrm{ml}$ diaminobenzidine (DAB) for about $5 \mathrm{~min}$ for coloring. After rinsing twice with PBS, the slides were treated with hematoxylin solution for nuclear staining, and then dehydrated and observed microscopically. For judging the immunohistochemical staining intensity of the $h M L H 1$ protein, the nuclei of endometrial stromal cells were used as an internal control; if the nuclei of the tumor cells containing the protein showed a stronger staining intensity than the control nuclei, the specimen was considered positive, whereas a specimen was considered negative if the tumor cell nuclei showed a lower staining intensity than the control nuclei (10). Regarding the E-cadherin staining, the protein is localized in the cell membrane in normal epithelial cells, and the immunohistochemical analysis was conducted in accordance with the criteria of Wu et al: Specimens with $\geq 25 \%$ of the tumor cells that stained for E-cadherin in the cell membrane were considered positive, and specimens with $<25 \%$ of the tumor cells giving this staining result were considered negative (11).

Statistical analysis. The correlation of the aberrant DNA methylation of the $h M L H 1, A P C$ and E-cadherin genes with the clinicopathological factors, grade of histological differentiation and cancer stage at surgery was analyzed using MannWhitney tests. The correlation of the aberrant DNA methylation of each of these genes with the patients' age was also examined, after confirming that the groups of patients with and without aberrant methylation showed a normal age distribution based on a normal distribution test. An F test was used to confirm that the population variances of the two independent groups were equal to each other, and then the differences in the population means were examined using the Student's t-test. The correlation of the aberrant DNA methylation level of $h M L H 1$ with those of APC, E-cadherin and $R A R-\beta$, respectively, was calculated using Fisher's exact test, and the correlations of the aberrant DNA methylation of hMLHI and E-cadherin with the immunohistochemical staining data were also examined using Fisher's exact test.

\section{Results}

Aberrant DNA methylation of cancer-related genes in endometrial specimens. Fig. 1 shows partial results of the MSP analysis of the endometrial cancer cells obtained using liquidbased cytology. A band due to the aberrant methylation of the hMLH1 gene was present in samples EC4 and EC17 (size, $112 \mathrm{bp}$ ), and bands due to the aberrant methylation of E-cadherin were found in samples EC20 and EC21 (206 bp). MSP analysis of the endometrial cancer specimens indicated that the frequencies of the aberrant methylation of the promoter regions were $40.4 \%(21 / 52)$ for $h M L H 1,22 \%(11 / 50)$ for $A P C$, $14 \%$ (7/50) for E-cadherin, and $2.3 \%$ (1/44) for RAR- $\beta$. No aberrant methylation was found in the promoter region of the 


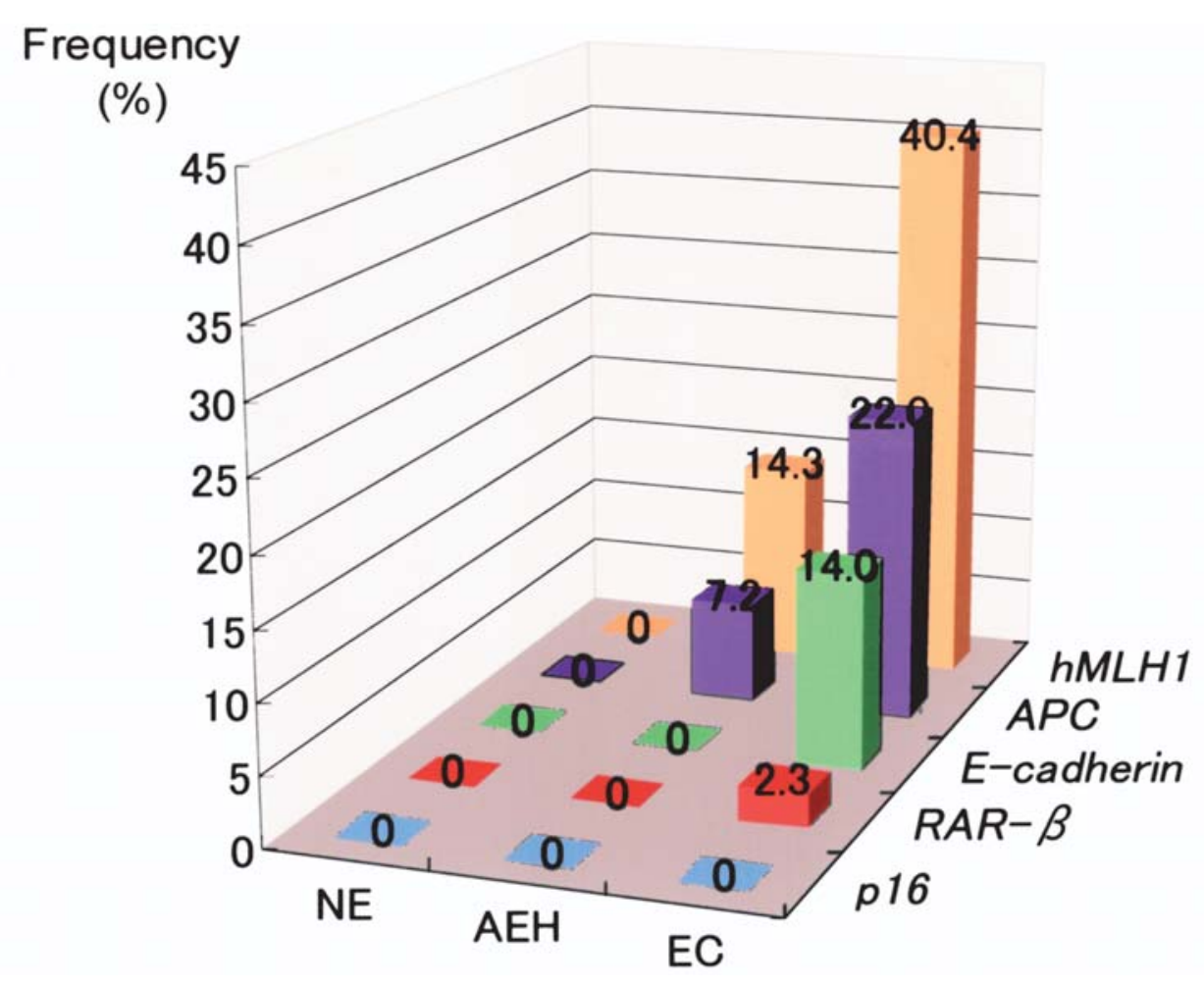

Figure 2. Frequencies of aberrant methylation of cancer-related genes in specimens from normal endometria, atypical endometrial hyperplasia and endometrial cancer. In the endometrial cancer specimens, hMLH1 exhibited the highest frequency of aberrant methylation, followed by APC and E-cadherin. Aberrant methylation of $h M L H 1$ was also found in atypical endometrial hyperplasia, whereas normal endometrial cells showed no aberrant methylation of the five genes. NE, normal endometrium; AEH, atypical endometrial hyperplasia; EC, endometrial cancer.

\begin{tabular}{|c|c|c|c|c|c|c|c|c|c|}
\hline Case & Age & Tissue type & $\begin{array}{c}\text { Cancer } \\
\text { stage }\end{array}$ & $\begin{array}{c}\text { Differen- } \\
\text { tiation } \\
\text { grade }\end{array}$ & HMLHI & E-cad & $A P C$ & RAR- $\beta$ & p16 \\
\hline EC1 & 52 & endometrioid adenocarcinoma & Ib & G3 & & & & & \\
\hline EC2 & 50 & endometrioid adenocarcinoma & Ia & G1 & & & & & \\
\hline EC3 & 51 & endometrioid adenocarcinoma & IIIc & G1 & & & & & \\
\hline EC4 & 54 & adenosquamous carcinoma & III0 & G3 & & & & & \\
\hline EC5 & 51 & endometrioid adenocarcinoma & Ia & G1 & & & & & \\
\hline EC6 & 61 & endometrioid adenocarcinoma & Ib & G1 & & & & & \\
\hline EC7 & 70 & endometrioid adenocarcinoma & IIIc & G2 & & & & & \\
\hline EC8 & 61 & endometrioid adenocarcinoma & II b & G1 & & & & & \\
\hline EC9 & 62 & adenosquamous carcinoma & III. & G2 & & & & & \\
\hline EC10 & 40 & endometrioid adenocarcinoma & IIa & a1 & & & & & \\
\hline EC11 & 59 & endometrioid adenocarcinoma & II a & G3 & & & & & \\
\hline EC12 & 57 & ondometrioid adenocarcinoma & Ib & G3 & & & & & \\
\hline EC13 & 80 & endometrioid adenocarcinoma & IIIC & G3 & & & & & \\
\hline EC14 & 54 & adenosquamous carcinoma & Ib & G1 & & & & & \\
\hline EC15 & 53 & endometrioid adenocarcinoma & Ib & G3 & & & & & \\
\hline EC16 & 42 & endometrioid adenocarcinoma & II b & G1 & & & & & \\
\hline EC17 & 71 & endometrioid adenocarcinoma & IIIC & Q3 & & & & & \\
\hline EC18 & 60 & endometrioid adenocarcinoma & Ib & a1 & & & & & \\
\hline EC19 & 57 & endometrioid adenocarcinoma & IIIa & G2 & & & & & \\
\hline $\mathrm{EC} 20$ & 71 & endometrioid adenocarcinoma & II a & G1 & & & & & \\
\hline EC21 & 37 & endometrioid adenocarcinoma & II a & G2 & & & & & \\
\hline EC22 & 47 & endometrioid adenocarcinoma & IIIb & G1 & & & & & \\
\hline EC23 & 67 & endometrioid adenocarcinoma & Io & G2 & & & & & \\
\hline EC24 & 53 & endometrioid adenocarcinoma & $\mathrm{Ia}$ & G1 & & & & & \\
\hline EC25 & 69 & endometrioid adenocarcinoma & III0 & G2 & & & & & \\
\hline EC26 & 55 & endometrioid adenocarcinoma & III0 & G2 & & & & & \\
\hline EC27 & 54 & endometrioid adenocarcinoma & Ia & G1 & & & & & \\
\hline EC28 & 63 & endometrioid adenocarcinoma & $\mathrm{Ia}$ & G1 & & & & & \\
\hline EC29 & 41 & endometrioid adenocarcinoma & Ib & G1 & & & & & \\
\hline
\end{tabular}

\begin{tabular}{|c|c|c|c|c|c|c|c|c|c|}
\hline Case & Age & Tissue type & $\begin{array}{c}\text { Cancer } \\
\text { stage }\end{array}$ & $\begin{array}{l}\text { Differen- } \\
\text { tiation } \\
\text { grade }\end{array}$ & ПММLHI & E-cad & $A P C$ & $\mid R A R-\beta$ & p16 \\
\hline EC30 & 62 & adenosquamous carcinoma & Ib & G1 & & & & & \\
\hline EC31 & 58 & endometrioid adenocarcinoma & Ib & G2 & & & & & \\
\hline EC32 & 56 & endometrioid adenocarcinoma & IIIC & G3 & & & & & \\
\hline EC33 & 71 & endometrioid adenocarcinoma & Ib & G2 & & & & & \\
\hline EC34 & 53 & adenosquamous carcinoma & Ib & G3 & & & & & \\
\hline EC35 & 50 & endometrioid adenocarcinoma & IIIa & G3 & & & & & \\
\hline EC36 & 42 & adenosquamous carcinoma & IIIC & G3 & & & & & \\
\hline EC37 & 55 & endometrioid adenocarcinoma & Io & G3 & & & & & \\
\hline EC38 & 34 & adenosquamous carcinoma & IIIC & G1 & & & & & \\
\hline EC39 & 61 & endometrioid adenocarcinoma & Io & G1 & & & & & \\
\hline EC40 & 61 & endometrioid adenocarcinoma & Is & G1 & & & & & \\
\hline EC41 & 61 & endometrioid adenocarcinoma & I b & G1 & & & & & \\
\hline EC42 & 59 & ondometrioid adenocarcinoma & Ib & G1 & & & & & \\
\hline EC43 & 55 & adenosquamous carcinome & IVb & G2 & & & & & \\
\hline EC44 & 54 & endometrioid adenocarcinoma & II a & G1 & & & & & \\
\hline EC45 & 57 & endometrioid adenocarcinoma & II a & G1 & & & & & \\
\hline EC46 & 56 & endometrioid adenocarcinoma & Ib & G2 & & & & & \\
\hline EC47 & 78 & endometrioid adenocarcinoma & Ib & Q3 & & & & & \\
\hline EC48 & 65 & endometrioid adenocarcinoma & Ib & G2 & & & & & \\
\hline EC49 & 37 & endometrioid adenocarcinoma & Ia & G1 & & & & & \\
\hline EC50 & 36 & endometrioid adenocarcinoma & Ia & G1 & & & & & \\
\hline EC51 & 26 & endometrioid adenocarcinoma & Ia & G1 & & & & & \\
\hline EC52 & 18 & endometrioid adenocarcinoma & $\mathrm{Ia}$ & G1 & & & & & \\
\hline
\end{tabular}

Figure 3. Aberrant methylation of the promoter regions of cancer-related genes in endometrial cancer. G1, well-differentiated; G2, moderately differentiated; $\mathrm{G} 3$, poorly differentiated; EC, endometrial cancer; E-cad, E-cadherin.

p16 gene. In the atypical endometrial hyperplasia samples, the frequencies of the aberrant methylation of the promoter regions were $14.3 \%(2 / 14)$ for $h M L H 1$ and $7.3 \%$ (1/14) for $A P C$.
Normal endometrial cells in the proliferative and secretory phases showed no aberrant methylation of the promoter regions of the five examined genes (Figs. 2-4). 


\begin{tabular}{|l|c|c|c|c|c|c|c|}
\hline Case & Age & $\begin{array}{c}\text { Tissue } \\
\text { type }\end{array}$ & hMLH1 & E-cad & APC & RAR- $\beta$ & p16 \\
\hline NE1 & 37 & sec & & & & & \\
\hline NE2 & 43 & sec & & & & & \\
\hline NE3 & 51 & sec & & & & & \\
\hline NE4 & 35 & sec & & & & & \\
\hline NE5 & 39 & sec & & & & & \\
\hline NE6 & 41 & sec & & & & & \\
\hline NE7 & 47 & sec & & & & & \\
\hline NE8 & 40 & sec & & & & & \\
\hline NE9 & 36 & sec & & & & & \\
\hline NE10 & 49 & sec & & & & & \\
\hline NE11 & 51 & sec & & & & & \\
\hline NE12 & 52 & sec & & & & & \\
\hline NE13 & 44 & sec & & & & & \\
\hline NE14 & 47 & sec & & & & & \\
\hline NE15 & 23 & sec & & & & & \\
\hline NE16 & 34 & sec & & & & & \\
\hline NE17 & 37 & pro & & & & & \\
\hline NE18 & 37 & pro & & & & & \\
\hline NE19 & 51 & pro & & & & & \\
\hline NE20 & 49 & pro & & & & & \\
\hline NE21 & 43 & pro & & & & & \\
\hline NE22 & 36 & pro & & & & & \\
\hline NE23 & 43 & pro & & & & & \\
\hline NE24 & 42 & pro & & & & & \\
\hline NE25 & 27 & pro & & & & & \\
\hline NE26 & 44 & pro & & & & & \\
\hline NE27 & 32 & pro & & & & & \\
\hline
\end{tabular}

\begin{tabular}{|c|c|c|c|c|c|c|}
\hline Case & Age & hMLH1 & E-cad & $A P C$ & RAR $-\beta$ & p16 \\
\hline AEH1 & 34 & & & & & \\
\hline AEH2 & 30 & & & & & \\
\hline AEH3 & 32 & & & & & \\
\hline AEH4 & 35 & & & & & \\
\hline AEH5 & 35 & & & & & \\
\hline AEH6 & 46 & & & & & \\
\hline AEH7 & 41 & & & & & \\
\hline AEH8 & 33 & & & & & \\
\hline AEH 9 & 41 & & & & & \\
\hline AEH10 & 50 & & & & & \\
\hline AEH11 & 45 & & & & & \\
\hline AEH12 & 47 & & & & & \\
\hline AEH13 & 45 & & & & & \\
\hline AEH14 & 33 & & & & & \\
\hline
\end{tabular}

Not done

Figure 4. Aberrant methylation of the promoter regions of cancer-related genes in atypical endometrial hyperplasia. AEH, atypical endometrial hyperplasia; $E$-cad, E-cadherin.

Immunohistochemical analysis of hMLH1 and E-cadherin protein expression. The relationship of the aberrant DNA methylation of the promoter regions of the $h M L H 1$ and $E$-cadherin genes with protein expression was determined immunohistochemically. Of the 20 surgical specimens of endometrial cancer showing aberrant methylation, most showed negative protein staining $(h M L H 1, \mathrm{p}<0.01 ; E-$ cadherin, $\mathrm{p}<0.05)$ (Fig. 5) (Table II).

Correlation of aberrant DNA methylation of cancer-related genes with clinicopathological factors. The correlations of the aberrant DNA methylation of the promoter regions of $h M L H 1$, $A P C$ and E-cadherin with the clinicopathological factors were examined in endometrial cancer patients. For the $h M L H 1$, APC and E-cadherin genes, no correlation was found between aberrant methylation and the grade of histological differentiation or with cancer stage at surgery. Aberrant DNA methylation is generally thought to increase with age, but no significant difference was found in the mean age between patients with and without aberrant methylation of $h M L H 1$, $A P C$ and E-cadherin, respectively. Therefore, these data do not indicate that aberrant methylation occurs more frequently in elderly patients with endometrial cancer (Table IV).

The relationship of the aberrant methylation of the promoter region of $h M L H 1$, which showed the highest frequency in the endometrial cancer samples, was also examined with that of other genes, but no correlation was found with the methylation of $A P C, E$-cadherin or $R A R-\beta$.

\section{Discussion}

Of the five endometrial cancer-related genes examined, the aberrant methylation of $h M L H 1$, a DNA mismatch repair gene, was found most frequently $(40.4 \%)$. The frequencies of the aberrant methylation of $h M L H 1$ have been reported as $14 \%$ to $26 \%$ in gastric cancer $(12,13)$ and $7 \%$ to $32 \%$ in lung cancer $(14,15)$; therefore, the frequency of the aberrant methylation of this gene in endometrial cancer is higher than in other cancers. After $h M L H 1$, the second most likely genes to show aberrant methylation were $A P C$ and E-cadherin, which are Wnt-related genes. Collectively, these data suggest that abnormal DNA mismatch repair and aberrant Wnt signaling are associated with endometrial carcinogenesis. However, patients with an aberrant methylation of $h M L H 1$ rarely corresponded to those with an aberrant methylation of E-cadherin, and therefore carcinogenesis due to the aberrant methylation of these respective genes may occur through independent mechanisms.

The aberrant methylation of $h M L H 1$ may cause a reduced protein expression that leads to abnormal DNA mismatch repair and MSI. However, although MSI has been found in $\sim 40 \%$ of patients with endometrial cancer, the $h M L H 1$ 

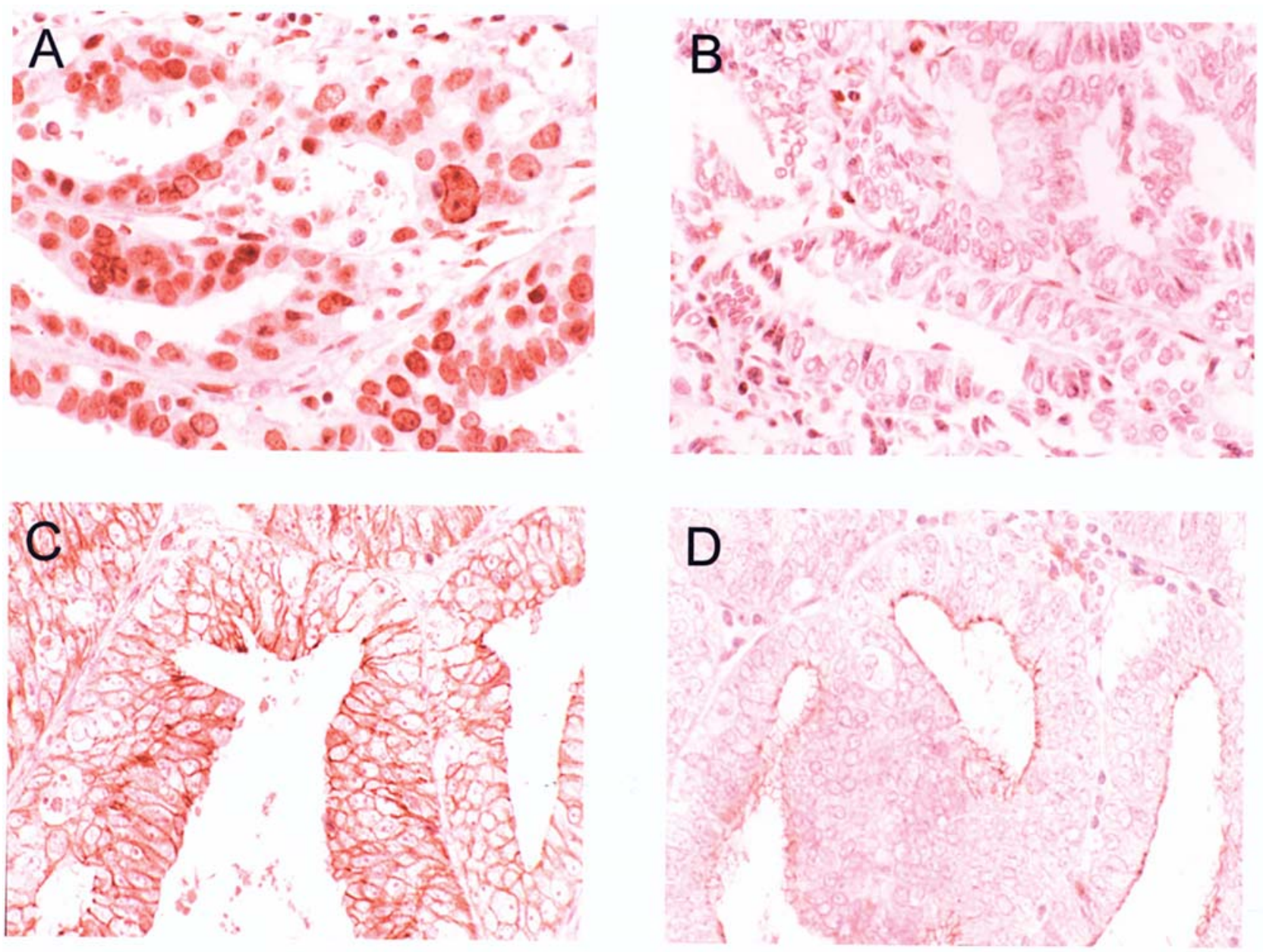

Figure 5. (A and B) Immunohistochemical analysis of the endometrial cancer specimens using the anti- $h M L H 1$ antibody. (A) In patients with an unmethylated $h M L H 1$ gene (EC23), the nuclei of the cancer cells were strongly stained. (B) In patients with aberrant methylation of $h M L H 1$ (EC31), the cell nuclei were less strongly stained. (C and D) Immunohistochemical analysis of the endometrial cancer specimens using the anti-E-cadherin antibody. (C) In patients with unmethylated E-cadherin (EC29), the cell membranes of the cancer cells were strongly stained. (D) In patients with aberrant methylation of E-cadherin (EC8), the cell membranes were less strongly stained. EC, endometrial cancer.

Table II. Relationship of the aberrant DNA methylation of the $h M L H 1$ and E-cadherin genes with reduced protein expression.

\begin{tabular}{lccc}
\hline & Expressed & $\begin{array}{c}\text { Not } \\
\text { expressed }\end{array}$ & \\
\hline$h M L H 1$ & 3 & 9 & $\mathrm{p}<0.01$ \\
methylated & 8 & 0 & \\
unmethylated & & & $\mathrm{p}<0.05$ \\
E-cadherin & 2 & 2 & \\
methylated & 15 & 1 & \\
unmethylated & & &
\end{tabular}

mutation frequency in MSI-positive endometrial cancer patients is extremely low $(16,17)$, suggesting that MSI may occur due to the aberrant methylation of the promoter regions, and not due to the $h M L H 1$ mutation. Furthermore, the aberrant methylation of $h M L H 1$ has been found in atypical endometrial hyperplasia, but is not observed in the normal endometrium;
Table III. Correlation of the aberrant DNA methylation of cancer-related genes with the grade of histological differentiation and clinical stage at surgery.

\begin{tabular}{|c|c|c|c|c|c|c|c|}
\hline & \multirow[t]{2}{*}{ G1 } & \multirow[t]{2}{*}{ G2 } & \multirow[t]{2}{*}{ G3 } & \multicolumn{4}{|c|}{ Stage } \\
\hline & & & & $\mathrm{I}$ & II & III & IV \\
\hline \multicolumn{8}{|c|}{$h M L H 1$} \\
\hline M & 12 & 6 & 3 & 11 & 4 & 5 & 1 \\
\hline $\mathrm{U}$ & 15 & 6 & 10 & 19 & 4 & 8 & 0 \\
\hline \multicolumn{8}{|c|}{ E-cadherin } \\
\hline M & 4 & 1 & 2 & 3 & 3 & 1 & 0 \\
\hline $\mathrm{U}$ & 22 & 11 & 10 & 24 & 5 & 13 & 1 \\
\hline \multicolumn{8}{|l|}{$A P C$} \\
\hline M & 5 & 2 & 4 & 7 & 2 & 2 & 0 \\
\hline $\mathrm{U}$ & 21 & 10 & 8 & 20 & 6 & 12 & 1 \\
\hline
\end{tabular}

G1, well-differentiated; G2, moderately differentiated; G3, poorly differentiated; M, methylated; U, unmethylated. 
Table IV. Correlation of the aberrant DNA methylation of cancer-related genes with the mean onset age of endometrial cancer.

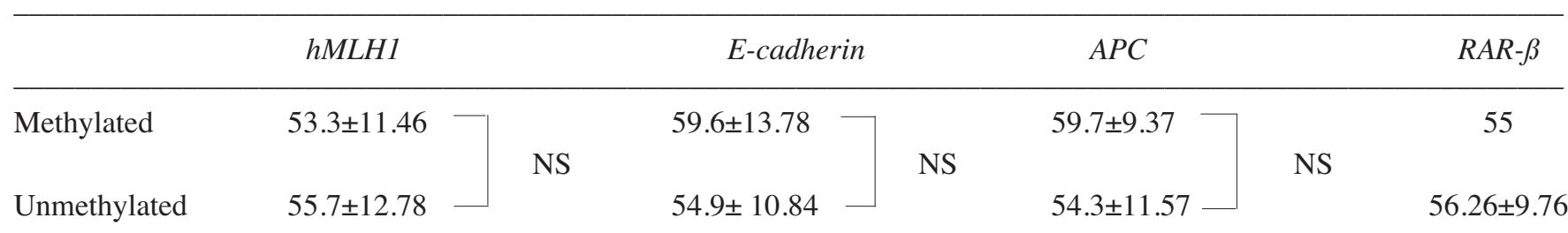

NS, not significant.

therefore, aberrant methylation occurs in the early stage of carcinogenesis. Since such aberrant methylation can be detected in a small amount of cytological material by using minimally invasive procedures, the determination of the methylation levels of genes such as $h M L H 1$ is a potential supplementary diagnostic method for endometrial cancer.

An accumulation of $\beta$-catenin in the nucleus, which indicates aberrant Wnt-signaling, has been observed in $23.8 \%$ of patients with endometrial cancer (18), and is thought to be one of the causes of endometrial cancer. In contrast, the $\beta$-catenin mutation frequency is only $11 \%$, significantly lower than the frequency of the accumulation of $\beta$-catenin in the nucleus (18). Furthermore, the accumulation of $\beta$-catenin in the nucleus has been observed in patients without $\beta$-catenin mutations; therefore, the transition and accumulation of $\beta$-catenin in the nucleus are dependent on a mechanism other than gene mutation. The aberrant methylation of the promoter region of E-cadherin, which codes for a scaffolding protein that binds to $\beta$-catenin and is present in the cell membrane as a cell adhesion molecule, was found in $14 \%$ of the patients with endometrial cancer in our patient population. Reduced levels of the E-cadherin protein were frequently observed in the patients with aberrant methylation of E-cadherin, suggesting that the inactivation of E-cadherin by aberrant methylation could be associated with changes in the localization of $\beta$-catenin in endometrial cancer. The aberrant methylation of E-cadherin has also been found in G3 adenocarcinoma (19), but no correlation with the localization of $\beta$-catenin has been investigated. The aberrant methylation of E-cadherin was not detected in the patients with atypical endometrial hyperplasia, which is considered pathologically to be Stage 0 endometrial cancer, but was found in the patients with Stage Ia or higher endometrial cancer. This suggests that the aberrant methylation of E-cadherin is not involved in early-stage carcinogenesis, in contrast to $h M L H 1$.

Similar to the aberrant methylation of the $h M L H 1$ gene, the aberrant methylation of $A P C$, a component of the Wnt signaling pathway, was observed in $7.3 \%$ of the patients with atypical endometrial hyperplasia and $22 \%$ of the patients with endometrial cancer; however, no reduction in the levels of the APC protein was observed. Therefore, our results indicate that there is no relationship between the inactivation of $A P C$ by aberrant methylation and the onset of endometrial cancer.

The frequencies of the aberrant methylation of $R A R-\beta$ and p16 were $2.3 \%$ and $0 \%$ in the endometrial cancer patients, respectively, which are significantly lower than those in cancers of other organs. These results suggest that the type and frequency of genes undergoing aberrant methylation in endometrial cancer are specific and differ from those in other cancers. The aberrant methylation of the promoter region of p16 has been reported in $20 \%$ of non-Japanese patients with endometrial cancer (20); the difference between this result and our study suggests that the frequencies of aberrant DNA methylation in endometrial cancer may also vary between races. Furthermore, aging is generally thought to be an important factor for aberrant DNA methylation, but we found no tendency for increased aberrant methylation in elderly patients with endometrial cancer. The mechanism of the induction of aberrant DNA methylation may also differ widely between organs and tissues (21), and this may account for the differences in results between the studies.

\section{Acknowledgements}

This study was partially supported by the Ministry of Education, Culture, Sports, Science and Technology through a Grant-in-Aid for Scientific Research (17791135), and by the Public Trust Haraguchi Memorial Cancer Research Fund. We are grateful to the Cytyc Corporation for the provision of ThinPrep.

\section{References}

1. Esteller M, Catasus L, Matias-Guiu X, Mutter GL, Prat J, Baylin SB and Herman JG: hMLH1 promoter hypermethylation is an early event in human endometrial tumorigenesis. Am J Pathol 155: 1767-1772, 1999.

2. Kanaya T, Kyo S, Maida Y, Yatabe N, Tanaka M, Nakamura M and Inoue M: Frequent hypermethylation of MLH1 promoter in normal endometrium of patients with endometrial cancers. Oncogene 22: 2352-2360, 2003.

3. Fukuchi T, Sakamoto M, Tsuda H, Maruyama K, Nozawa S and Hirohashi S: Beta-catenin mutation in carcinoma of the uterine endometrium. Cancer Res 58: 3526-3528, 1998.

4. Peiffer SL, Bartsch D, Whelan AJ, Mutch DG, Herzog TJ and Goodfellow PJ: Low frequency of CDKN2 mutation in endometrial carcinomas. Mol Carcinog 13: 210-212, 1995.

5. Nakashima R, Fujita M, Enomoto T, Haba T, Yoshino K, Wada H, Kurachi H, Sasaki M, Wakasa K, Inoue M, Buzard G and Murata $\mathrm{Y}$ : Alteration of p16 and p15 genes in human uterine tumours. Br J Cancer 80: 458-467, 1999.

6. Sasaki M, Dharia A, Oh BR, Tanaka Y, Fujimoto S and Dahiya R: Progesterone receptor $\mathrm{B}$ gene inactivation and $\mathrm{CpG}$ hypermethylation in human uterine endometrial cancer. Cancer Res 61: 97-102, 2001.

7. Widschwendter M, Berger J, Hermann M, Muller HM, Amberger A, Zeschnigk M, Widschwendter A, Abendstein B, Zeimet AG, Daxenbichler G and Marth C: Methylation and silencing of the retinoic acid receptor-beta2 gene in breast cancer. J Natl Cancer Inst 92: 826-832, 2000. 
8. Ueki T, Toyota M, Skinner H, Walter KM, Yeo CJ, Issa JP, Hruban $\mathrm{RH}$ and Goggins $\mathrm{M}$ : Identification and characterization of differentially methylated $\mathrm{CpG}$ islands in pancreatic carcinoma. Cancer Res 61: 8540-8546, 2001.

9. Susumu N, Aoki D, Noda T, Nagashima Y, Hirao T, Tamada Y, Banno K, Suzuki A, Suzuki N, Tsuda H, Inazawa J and Nozawa S: Diagnostic clinical application of two-color fluorescence in situ hybridization that detects chromosome 1 and 17 alterations to direct touch smear and liquid-based thin-layer cytologic preparations of endometrial cancers. Int J Gynecol Cancer 15: 70-80, 2005.

10. Banno K, Susumu N, Hirao T, Yanokura M, Hirasawa A, Aoki D, Udagawa Y, Sugano K and Nozawa S: Two Japanese kindreds occurring endometrial cancer meeting new clinical criteria for hereditary non-polyposis colorectal cancer (HNPCC), Amsterdam Criteria II. J Obstet Gynaecol Res 30: 287-292, 2004.

11. Wu ZY, Zhan WH, Li JH, He YL, Wang JP, Lan P, Peng JS and Cai SR: Expression of E-cadherin in gastric carcinoma and its correlation with lymph node micrometastasis. World J Gastroenterol 11: 3139-3143, 2005.

12. Oue N, Oshimo Y, Nakayama H, Ito R, Yoshida K, Matsusaki K and Yasui W: DNA methylation of multiple genes in gastric carcinoma: association with histological type and $\mathrm{CpG}$ island methylator phenotype. Cancer Sci 94: 901-905, 2003.

13. Hong SH, Kim HG, Chung WB, Kim EY, Lee JY, Yoon SM, Kwon JG, Sohn YK, Kwak EK and Kim JW: DNA hypermethylation of tumor-related genes in gastric carcinoma. J Korean Med Sci 20: 236-241, 2005.

14. Chen G, Liu T and He J: Status of methylation of promoter of mismatch repair gene hMLH1 in lung cancer. Chung Hua Chung Liu Tsa Chih 22: 493-495, 2000.
15. Yanagawa N, Tamura G, Oizumi H, Takahashi N, Shimazaki Y and Motoyama T: Promoter hypermethylation of tumor suppressor and tumor-related genes in non-small cell lung cancers. Cancer Sci 94: 589-592, 2003.

16. Baldinu P, Cossu A, Manca A, Satta MP, Pisano M, Casula M, Dessole S, Pintus A, Tanda F and Palmieri G: Microsatellite instability and mutation analysis of candidate genes in unselected Sardinian patients with endometrial carcinoma. Cancer 94: 3157-3168, 2002.

17. Kowalski LD, Mutch DG, Herzog TJ, Rader JS and Goodfellow PJ: Mutational analysis of MLH1 and MSH2 in 25 prospectively-acquired RER+ endometrial cancers. Genes Chromosomes Cancer 18: 219-227, 1997.

18. Moreno-Bueno G, Hardisson D, Sanchez C, Sarrio D, Cassia R, Garcia-Rostan G, Prat J, Guo M, Herman JG, Matias-Guiu X, Esteller M and Palacios J: Abnormalities of the APC/betacatenin pathway in endometrial cancer. Oncogene 21: 7981-7990, 2002.

19. Saito T, Nishimura M, Yamasaki H and Kudo R: Hypermethylation in promoter region of E-cadherin gene is associated with tumor dedifferention and myometrial invasion in endometrial carcinoma. Cancer 97: 1002-1009, 2003.

20. Wong YF, Chung TK, Cheung TH, Nobori T, Yu AL, Batova A, Lai KW and Chang AM: Methylation of p16INK4A in primary gynecologic malignancy. Cancer Lett 136: 231-235, 1999.

21. Yanokura M, Banno K, Susumi N, Kwaguchi M, Kuwabara Y, Tsukazaki K and Aoki D: Hypermethylation in the p16 promoter region in the carcinogenesis of endometrial cancer in Japanese patients. Anticancer Res 26: 851-856, 2006. 